\title{
Antipatharian corals of Ascension Island
}

\author{
DENNIS M. OPRESKO \\ US National Museum of Natural History, Smithsonian Institution, Washington, DC, USA
}

Seven species of antipatharian corals (Cnidaria: Anthozoa: Antipatharia) are recorded from Ascension Island; five of these for the first time. Tanacetipathes spinescens and Stichopathes occidentalis were the two most commonly collected species.

Keywords: black corals, South Atlantic, Ascension Island

Submitted 28 November 2013; accepted 29 April 2014; first published online 17 June 2014

\section{INTRODUCTION}

Prior to this publication, only two species of antipatharian corals, Taxipathes recta Brook (1889) and Cladopathes plumosa Brook (1889) were recorded from Ascension Island. A third species from Ascension, Dendrobrachia fallax, originally thought to be an antipatharian, was later shown to be a gorgonian coral (Opresko \& Bayer, 1991). Both T. recta and C. plumosa are deep-water species that were collected during the voyage of HMS 'Challenger'. In this paper a third deep-water species, as well as four shallowwater antipatharian species are described from Ascension for the first time, and the relationship of the shallow-water fauna to the eastern Atlantic fauna is discussed.

\section{MATERIALS AND METHDDS}

In addition to a review of the pertinent literature, the collections of the U.S. National Museum of Natural History (USNMNH) of the Smithsonian Institution, Washington, DC, were surveyed for records of antipatharian corals collected at Ascension Island. Eleven specimens were found in the USNMNH collections, nine from shallow-water at depths of $32 \mathrm{~m}$ or less (Note: USNMNH catalogue numbers are prefixed with USNM). The survey of the open literature revealed records of two, primarily deep-water species that were reported as being collected near Ascension Island, one from within $10 \mathrm{~km}$ of the island (a subsample of one of these is also in the USNM collection). In total, there are twelve records of specimens from the area, representing seven species in six genera and four families.

\section{RESULTS}

\section{SYSTEMATICS \\ ANTIPATHIDAE \\ Stichopathes occidentalis (Gray, 1860) (Figure 1A)}

Three Ascension Island specimens of this species are in the USNMNH collections; two were collected off Boatswain Bird Rock, one from the vertical face of a drop-off at $28 \mathrm{~m}$

Corresponding author:

D.M. Opresko

Email: dmopresko@hotmail.com depth (USNM 99872), the second growing from the side of a large boulder at $30 \mathrm{~m}$ (USNM 99546). The third specimen was found south of Southwest Bay at a depth of $32 \mathrm{~m}$ (USNM 1229810).

The species $S$. occidentalis was originally described from Turk's Island in the West Indies (Gray, 1860). It was later reported from the west coast of Africa (Islas das Rolas) by Broch (1920). The Ascension Island specimens differ from the type of $S$. occidentalis in having spines that are slightly more acute, although in respect to size (about $0.2 \mathrm{~mm}$ ) and surface ornamentation, they are quite similar. A similar

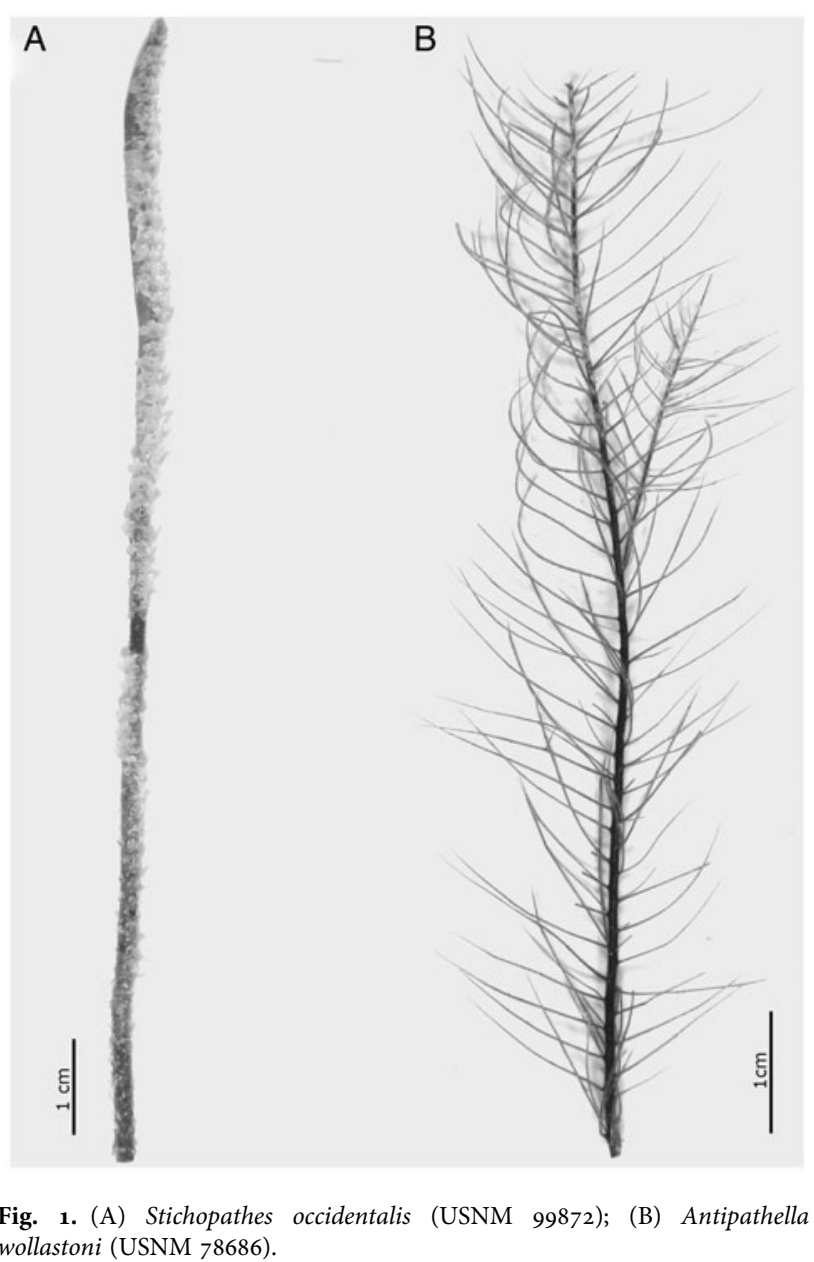


morphotype occurs in Bermuda at depths of $73-110 \mathrm{~m}$ (unpublished observations).

\section{MYRIOPATHIDAE \\ Antipathella wollastoni (Gray, 1857) (Figure 1B)}

Two Ascension Island specimens of this species are in the USNMNH collection, one collected off the east end of the island at a depth of $6 \mathrm{~m}$ (USNM 78686) and the other south of Southwest Point at $32 \mathrm{~m}$ (USNM 79389). The species is only known from the eastern Atlantic; it has been recorded from Madeira, Cape Verde, the Azores and the Canary Islands (see Brito \& Ocaña, 2004), as well as from the western Mediterranean (Ocaña et al., 2006). It forms rather large bushy colonies with elongate branchlets. It is similar in general morphology to Antipathella subpinnata which is known primarily from the Mediterranean.

Tanacetipathes spinescens (Gray, 1857) (Figure 2)

Three Ascension Island specimens of this species are in the USNMNH collections; one collected off the south-west end of the island in $20 \mathrm{~m}$ (USNM 78687); the second from south of Southwest Bay in $32 \mathrm{~m}$ (USNM 79390); and the third from off Portland Point in $24 \mathrm{~m}$ (USNM 99680). This species forms bushy, densely pinnulated colonies. Branches arise from all parts of the colony. The species was originally described from Cape Palmas (Gray, 1857). A very similar if not identical species is Tanacetipathes squamosa (Koch, 1886) described from Islas das Rolas in the Gulf of Guinea. The two species were synonymized by Broch (1920).
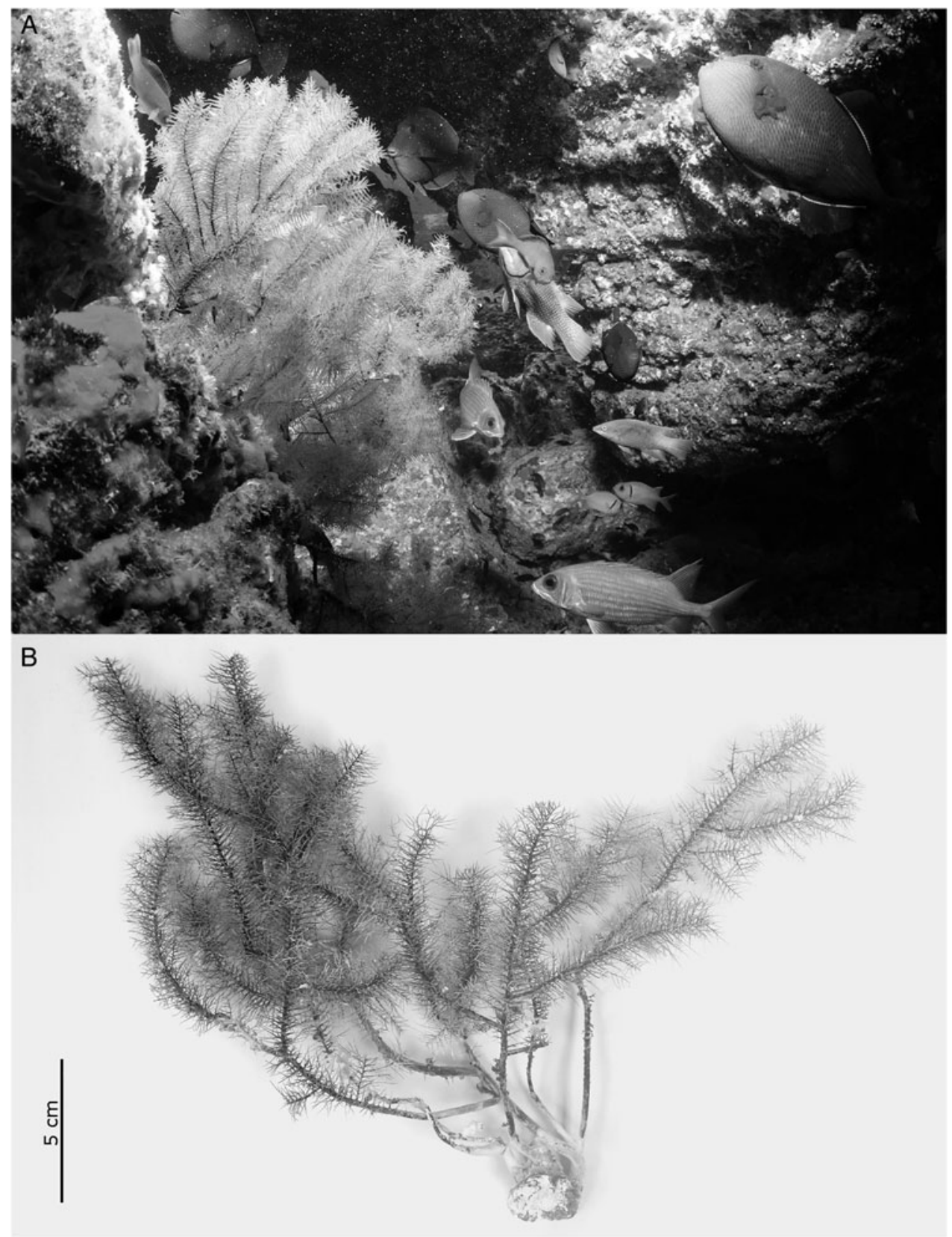

Fig. 2. Tanacetipathes spinescens. (A) In situ (photograph: Shallow Marine Surveys Group); (B) USNM 99680. 


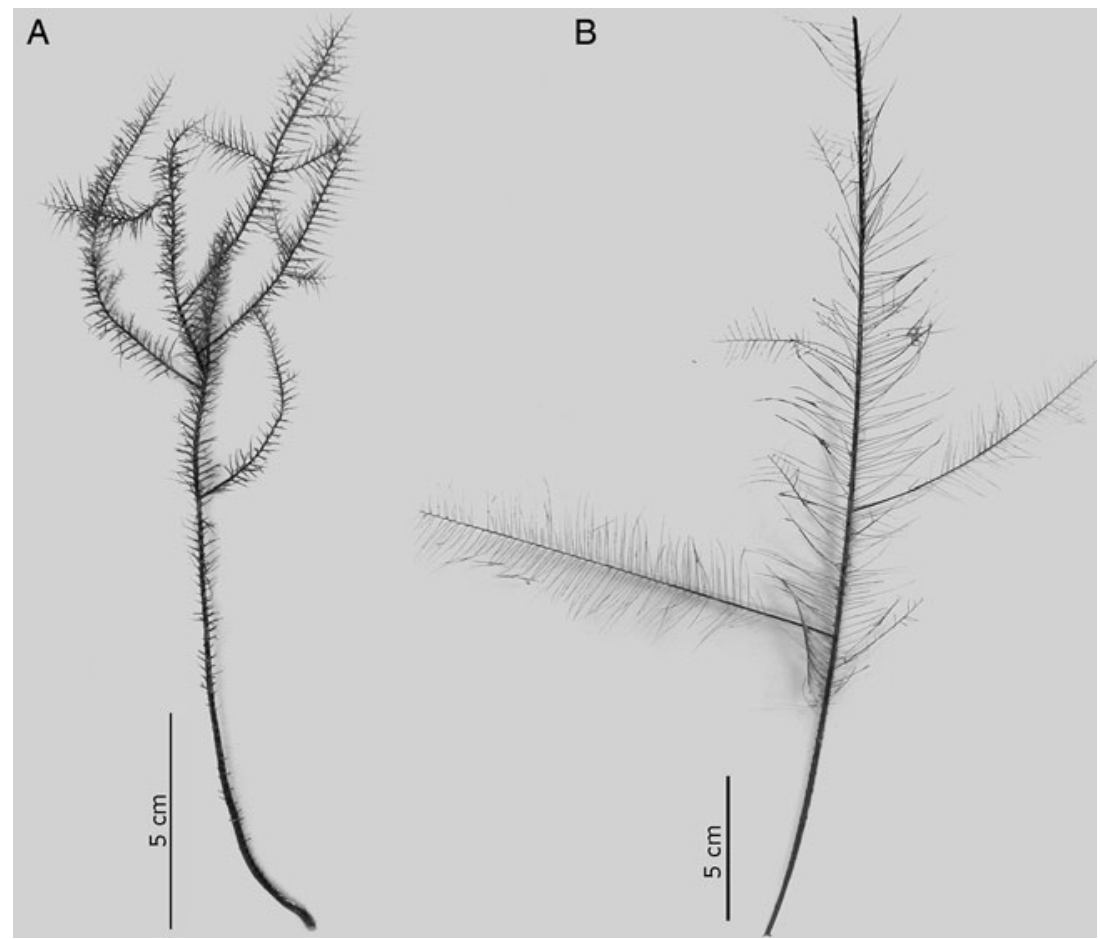

Fig. 3. (A) Tanacetipathes cf. cavernicola (USNM 78688); (B) Lillipathes sp. (USNM 91419).

\section{Tanacetipathes cf. cavernicola Opresko, 2001 (Figure 3A)}

Tanacetipathes cavernicola was originally described from Madeira where it was found growing in an underwater cave at a depth of 9-10 m (Opresko, 2001). It has also been reported from the Canary Islands (Brito \& Ocaña, 2004). The specimen from Ascension Island was collected off the east end of the island (USNM 78688; depth not recorded). It differs from the type in having more secondary pinnules on the posterior primary pinnules.

\section{SCHIZOPATHIDAE}

Lillipathes sp. (Figure ${ }_{3} \mathrm{~B}$ )

The genus Lillipathes Opresko (2002) is known primarily from the Pacific. This is the first published record from the Atlantic. The specimen from Ascension Island (USNM 91419) was collected in $586 \mathrm{~m}$ by the RV 'Oman Sea I' (6 August 1991); however, the exact location was not recorded. Species of Lillipathes are characterized by having simple pinnules arranged in four longitudinal rows along the stem and branches, and also with the pinnules grouped together in alternating pairs. Species are differentiated by the length and density of the pinnules, and size of the polyps and spines. The specimen from Ascension Island resembles $L$. wingi Opresko, 2005, in terms of the length and density of the pinnules; however, it differs from that species in having slightly smaller spines (0.06 vs $0.1 \mathrm{~mm}$ ).

\section{Taxipathes recta Brook, 1889 (Figure 4A)}

This species was originally described in the 'Challenger' Report (Brook, 1889). The type was collected approximately $6.5 \mathrm{~km}$ west of Ascension Island $\left(7^{\circ} 54^{\prime} 20^{\prime \prime} \mathrm{S} 14^{\circ} 28^{\prime} 20^{\prime \prime} \mathrm{W}\right)$ at a depth of 420 fathoms $(768 \mathrm{~m})$. It has not been reported from any other locality. The species forms branched, pinnulated colonies with simple pinnules arranged bilaterally and in alternating semispiral groups of three. The arrangement of the pinnules is very similar to that which occurs in colonies of Parantipathes.

\section{CLADOPATHIDAE}

Cladopathes plumosa Brook, 1889 (Figure 4B)

According to the records of the Natural History Museum, London, a specimen identified as this species (Reg. No. 1889.7.9.9a) was collected off Ascension Island during the 'Challenger' Expedition (see Opresko, 2003). The depth and exact locality were not recorded. The species was first described by Brook (1889) from the Prince Edward Islands in the Indian Ocean. It was collected at a depth of 310 fathoms $(558 \mathrm{~m})$. The species forms large, branched, pinnulated colonies (see Opresko, 2003, for detailed description). The pinnulation pattern varies in regularity. The primary pinnules are arranged mostly in clusters of three (rarely two or four). The anteriormost primary pinnules usually have one or two secondary pinnules (range $0-4$ ), and the posterior primary pinnules are usually simple (rarely subpinnulate). Tertiary pinnules are sometimes present on secondary pinnules. Subpinnules may occur in subopposite pairs. In the specimen from Ascension Island the pinnules are more evenly spaced than in the type, the secondary pinnules sometimes occurring in groups of three as well as in subopposite pairs, and some of the secondary pinnules have subopposite pairs of tertiary pinnules.

\section{DISCUSSIDN}

The shallow-water antipatharian fauna of Ascension Island shows its closest affiliation to the fauna of the eastern Atlantic. Of the four shallow-water species, three are only 

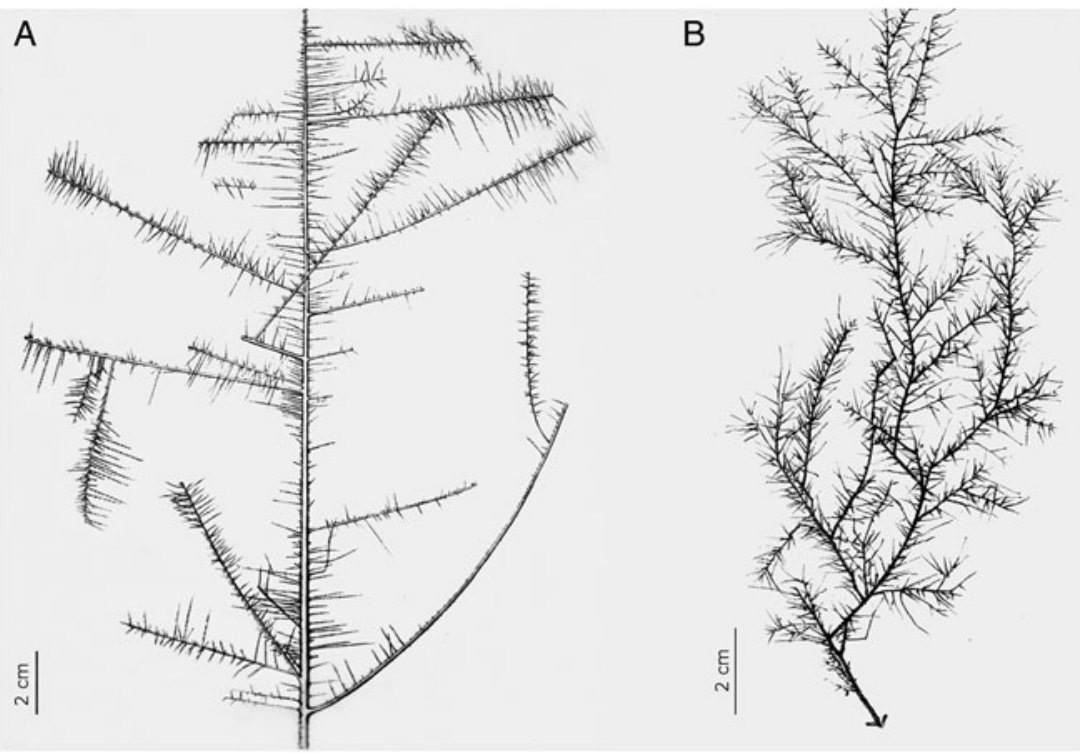

Fig. 4. (A) Taxipathes recta Brook, 1889, digital scan of original illustration (Brook, 1889, pl. 7, fig. 1); (B) Cladopathes plumosa Brook, 1889, digital scan of original illustration (Brook, 1889, pl. 2, fig. 3).

known from the eastern Atlantic and one is amphi-Atlantic. Tanacetipathes spinescens and Stichopathes occidentalis were the two most commonly collected shallow-water species.

\section{ACKNDWLEDGEMENTS}

The author wishes to thank the individuals who collected the Ascension Island antipatharians and donated them to the Smithsonian Institution, including R. Irving, J. Taylor, M. Mcdowell and the staff of the Grice Marine Biological Laboratory. Many thanks also to T. Molodtsova, M. Bo and a third anonymous referee for their comments and suggestions. We are grateful to the Shallow Marine Surveys Group and the South Atlantic Environmental Research Institute for organizing the expedition. We are also very grateful to the Ascension Island Government, the members of staff at the Conservation Centre and Ascension Island Dive Club for their cooperation, accommodation and hospitality. Finally we are grateful to British Forces South Atlantic Islands for their logistic support.

\section{FINANCIAL SUPPDRT}

The funding for this work came from a grant to the Shallow Marine Surveys Group from the Darwin Initiative (EIDCFo12). Funding for the author's research was provided, in part, by a grant from the US Department of Justice to the Smithsonian Institution.

\section{REFERENCES}

Brito A. and Ocaña Ó. (2004) Order Antipatharia. In Lemus F. (ed.) Corals of the Canary Islands. Skeletal Anthozoa of the littoral and deep bottoms. La Laguna: Francisco Lemus, pp. 318-342.

Broch H. (1920) Antipatharia. Beiträge zur Kenntnis der Meeresfauna West Afrikas 3, 18-22.
Brook G. (1889) Report on the Antipatharia. Reports of the Scientific Results of the Voyage of the 'Challenger', Zoology 32, 1-222.

Gray J.E. (1857) Synopsis of the families and genera of axiferous zoophytes or barked corals. Proceedings of the Zoological Society of London 25, 278-294.

Gray J.E. (1860) Notice of new corals from Madeira discovered by J.Y. Johnson, Esq. Annals of the Magazine of Natural History (Series 3) 6, 311.

Koch W.D.J. (1886) Ueber die von Herrn Prof. D. Greeff im Golf von Guinea gesammelten Anthozoen. PhD thesis. University of Bonn, Germany.

Ocaña O., Opresko D.M. and Brito A. (2006) First record of the black coral Antipathella wollastoni (Anthozoa: Antipatharia) outside of Macaronesian waters. Revista de la Academia Canaria de Ciencias $18,125-138$.

Opresko D.M. (2001) New species of antipatharians (Cnidaria: Anthozoa) from Madeira, with the establishment of a new genus. Proceedings of the Biological Society of Washington 114, 349-358.

Opresko D.M. (2002) Revision of the Antipatharia (Cnidaria: Anthozoa). Part II. Schizopathidae. Zoologische Mededelingen, Leiden 76, 411-442.

Opresko D.M. (2003) Revision of the Antipatharia (Cnidaria: Anthozoa). Part III. Cladopathidae. Zoologische Mededelingen, Leiden 77, 495-536.

Opresko D.M. (2005) New genera and species of antipatharian corals (Cnidaria: Anthozoa) from the North Pacific. Zoologische Mededelingen, Leiden 79, 129-165.

and

Opresko D.M. and Bayer F.M. (1991) Rediscovery of the enigmatic coelenterate Dendrobrachia, (Octocorallia: Gorgonacea) with descriptions of two new species. Transactions of the Royal Society of South Australia $115,1-19$.

\section{Correspondence should be addressed to:}

D.M. Opresko

US National Museum of Natural History, Smithsonian Institution, Washington, DC, USA, 20560

email: dmopresko@hotmail.com 